Turkish Online Journal of Qualitative Inquiry (TOJQI)

Volume 12, Issue 2, April 2021: 329-356

DOI: $10.17569 /$ tojqi.851525

Research Article

\title{
Understanding the Multiple Effects of Historical Empathy: A Study Explanatory Mixed Method $^{1,2}$
}

Sezgin Elbay ${ }^{3}$, Erdoğan Kaya ${ }^{4}$

\begin{abstract}
The aim of this research is "Understanding the effects of historical empathy model on academic achievement and attitudes towards the lesson of Turkish Republic (T.R.) Revolution History and Kemalism". To realize the research aim, explanatory mixed method design was administered. Within that context, firstly, quantitative method was used. Next, qualitative method was employed in order to explain quantitative data. In the quantitative stage, academic achievement test and attitudes towards the lesson scale were used as data collection tools; in qualitative stage video camera and semi-structured interview form were administered. Quantitative data of the research were analyzed via $T$ tests, Manova and One-Way Covariance Analysis whilst qualitative data were solved via thematic analysis. Analysis of quantitative data revealed that historical empathy model had statistically significant $(p<0,5)$ effect on students' academic achievement levels and their mean scores in attitudes towards the lesson. It was detected that historical empathy contributed to academic achievement by developing multiple literacies and motivated them to take historical context into account; since the method unveiled a range of emotional reactions, it was useful to help them develop positive attitudes towards the lesson.
\end{abstract}

Keywords: T.R. Revolution History and Kemalism lesson, historical empathy, explanatory mixed method.

\footnotetext{
${ }^{1}$ This article was produced from first author's doctoral thesis entitled "Investigation the effect of historical empathy model applied in Middle School Republic of Turkey Revolution History and Kemalism lesson on academic achievement and attitude for lesson".

${ }^{2}$ Research permission no. 29065503-44-E.18609769 (01.10.2019) was obtained by National Education Directorate of Sakarya Province.

${ }^{3}$ Dr., Ministry of National Education, sezgin_elbay@hotmail.com, ORCID ID: 0000-0002-0601-8063

${ }^{4}$ Prof. Dr., Anadolu University, Faculty of Education, Department of Turkish and Social Sciences Education, erkaya@anadolu.edu.tr, ORCID ID: 0000-0002-3930-7937

Receieved: 28.01.2021, Accepted: 23.01.2021
} 


\section{Tarihsel Empatinin Çoklu Etkilerini Anlamak: Bir Açıklayıcı Karma Yöntem Çalışması}

$\ddot{O} z$

Bu araştırmanın amacı, “Türkiye Cumhuriyeti (T.C.) İnkılap Tarihi ve Atatürkçülük dersinde, tarihsel empati modelinin, akademik başarı ile derse yönelik tutum üzerindeki etkilerini anlamak”tır. Araştırmanın amaçlarını gerçekleştirmek için açıklayıcı karma yöntem deseni işe koşulmuştur. Bu bağlamda öncelikle nicel; ardından nicel verileri açıklamak için nitel yöntem kullanılmıştır. Araştırmanın nicel aşamasında veri toplama araçları olarak, akademik başarı testi ile derse yönelik tutum ölçeği; nitel aşamasında video kamera ve yarı yapılandırılmış görüşme formu işe koşulmuştur. Araştırmanın nicel verileri, $\mathrm{t}$ testleri, Manova ve Tek Yönlü Kovaryans Analizi ile nitel verileri ise tematik analizle çözümlenmiştir. Nicel verilerin analizi sonucunda, tarihsel empati modelinin öğrencilerin akademik başarı düzeylerine istatistiksel olarak anlamlı $(\mathrm{p}<0,5)$ bir etkisinin olduğu ve derse yönelik tutum ortalamalarını arttırdığ 1 saptanmıştır. Tarihsel empatinin, öğrencilerin, çoklu okuryazarlıklar geliştirme ve tarihsel bağlamı dikkate almalarını sağlayarak akademik başarılarını olumlu olarak etkilediği; çeşitli duygusal tepkilerini açığa çıkardığı için de derse yönelik olumlu tutumlar geliştirmelerini sağladığg tespit edilmiştir.

Anahtar Sözcükler: T.C. Inkılap Tarihi ve Atatürkçülük dersi, tarihsel empati, açıklayıcı karma yöntem. 


\section{Introduction}

Historical empathy stems from a viewpoint that theoretical perspectives, value, belief and norms of the past differ from theoretical perspectives, value, belief and norms of present day. In this regard it can be argued that historical empathy is an attempt focusing on understanding the past with respect to its own circumstances. An attempt to understand the events could demand making historical comments according to the conditions of its age. In addition, that could also demand engaging in historical criticism and questioning (Foster, 2001). It can also be claimed that during its conceptual change process, historical empathy was used to meet a range of other objectives.

At the onset of 1970s, historical empathy was integrated into British Education system in a manner to involve historical criticism and questioning (Dillenburg, 2017). That new approach fueled opposition among those who advocated Perennialist and Fundamentalist educational ideologies in history teaching because according to them, cultural values of the past should be transferred to next generations with no changes (Y1lmaz, 2011). Opponents argued that historical empathy was a futile work and they criticized teaching historical empathy during history lessons which were already given in limited periods. Main focus of the criticism involved analysis of past values and interrogation of historical personalities. In subsequent decades (end of 1970s) history teachers began to employ historical empathy by blending it with psychological empathy and sympathy (Bartelds, Savenije and Boxtel, 2020).

Historical empathy was utilized by history teachers within an emotional context. In subsequent years that situation was criticized by those who actually conceptualized historical empathy in person. Critiques pointed out that historical empathy was neither psychological empathy nor sympathy. In this regard Shemilt in 1984 and Ashby and Lee in 1987 introduced to the field the very first theoretical frames that excluded emotions from historical empathy (Elbay, 2020b). Finally it can be argued that conceptual confusion in that field and incorrect use of historical empathy enabled to develop theoretical frames and these theoretical frames helped to identify historical empathy levels that consisted of cognitive dimension. Formed by cognitive dimension, principles of historical empathy were conceptualized by Foster (2001). In recent studies however; Barton and Levstik (2004) reported that in the past, emotions were 
misused and historical empathy should in fact entail a kind of interest -also known as "caring"towards historical events and personalities. In that way the role of emotions in historical empathy became a hot topic that initiated relevant researches. As a result of such researches, it has now become an accepted norm that historical empathy is a concept consisting of two dimensions as cognitive and affective. Affective dimension of historical empathy included over-sensation, identification, sympathy and empathy since they cover unique connections formed with an event or person and focus on time contextually (Jun, 2020). In fact affective dimension is analyzed in accordance with other factors like not belittling historical personalities and caring, paying value to their legacy. In this regard Endacott and Brooks (2013) also stated that emotions should be accounted together with cognitive dimension and they supported dual dimension of historical empathy. Within this framework it is safe to argue that historical empathy studies were conducted to examine several situations.

In conducted studies it was revealed that historical empathy was unrelated with psychological empathy (Dillenburg, 2017). In addition, effects of various strategies throughout historical empathy process were investigated and it became apparent that first and third person singular narration on the historical events experienced by historical personalities were influential in instilling historical empathy (Brooks, 2008; De Leur, Boxtel and Wilschut, 2017). Added to that, in the studies by Bryant and Clark (2006) and Metzger (2012) it was detected that a dramatic movie; a museum in Savenije and De Bruijn (2017) research had a positive effect on historical empathy. Moreover in the studies by Kosti, Kondoyianni and Tsiaras (2015) and Güneş (2019) drama was reported to play role in instilling historical empathy. In scale development trial by Çalışkan and Demir (2019) it was detected that historical empathy was formed of two dimensions (factors); cognitive and affective. In this regard Elbay's (2020b) study highlighted that affective and cognitive learning activities caused dissimilar effects. Although a great number of studies have discussed employed strategies in gaining historical empathy and reflections of these strategies, only a very small number of researches focused on the effect of historical empathy in academic achievement and attitude (Çorapç1, 2019). In these rare studies, it was seen that effect of teaching via historical empathy model developed by Endacott and Brooks (2013) on academic achievement and attitude was not investigated. Also, the kind of factors that molded students' academic achievement and attitudes towards the lesson during historical empathy process were left untreated. In sum it can be claimed that in literature there is emergent need for updated researches on the effect of historical empathy. It was also 
witnessed that in those studies there was a uniform tendency in method part. That being said, it can be argued that in those studies most common methods were qualitative method and case study. In another saying, there are very few studies with quantitative and mixed methods.

In Middle School T. R. Revolution History and Kemalism lesson, effects of historical empathy model on academic achievement and attitudes towards the lesson as well as relevant causes could be unveiled in researches with mixed method. Hence, multiple effects of the model could be learnt. Moreover, presenting the experiences of students undergoing historical empathy process could be useful in developing the model and could motivate the students to analyze past and present events according to prevailing circumstances. Accordingly, the aim of this research is teaching of history topics in accordance with historical empathy model that was developed by Endacott and Brooks (2013). Next, it is aimed to identify the effects of this model on the academic achievement in Middle School T.R. Revolution History and Kemalism lesson and attitude while also revealing relevant causes. Sub-questions developed in that line are such:

1. Between test group where lessons are offered in historical empathy model and control group in which lessons are offered in traditional teaching;

a. With respect to academic achievement; Is there a significant difference between pretest and posttest mean scores?

b. With respect to attitude towards Middle School T.R. Revolution History and Kemalism lesson; Is there a significant difference between pretest and posttest mean scores?

2. What are the views of 8 th grade students about historical empathy process?

3. How can the qualitative data obtained from 8th grade students in Middle School T.R. Revolution History and Kemalism lesson be useful in understanding the results of experimental procedure aimed at testing the effect of historical empathy model on academic achievement and attitudes towards the lesson?

\section{Methodology}

In answering research questions, explanatory mixed method design was harnessed. In this design firstly quantitative data are collected; next qualitative data are obtained in order to explain quantitative data (Creswell and Plano Clark, 2018). This research also integrated 
hypotheses of explanatory design and in this design the aim is to combine quantitative and qualitative methods as staged during many of the phases so as to guide the process of connecting data collection, time of the analysis and findings. Figure 1 displays the workflow in the research.

\section{Research process:}

Pre, during and post process screenings (with 50 participants)

Key target areas

Academic achievement and attitude towards the lesson

Students' reactions and views on historical empathy process

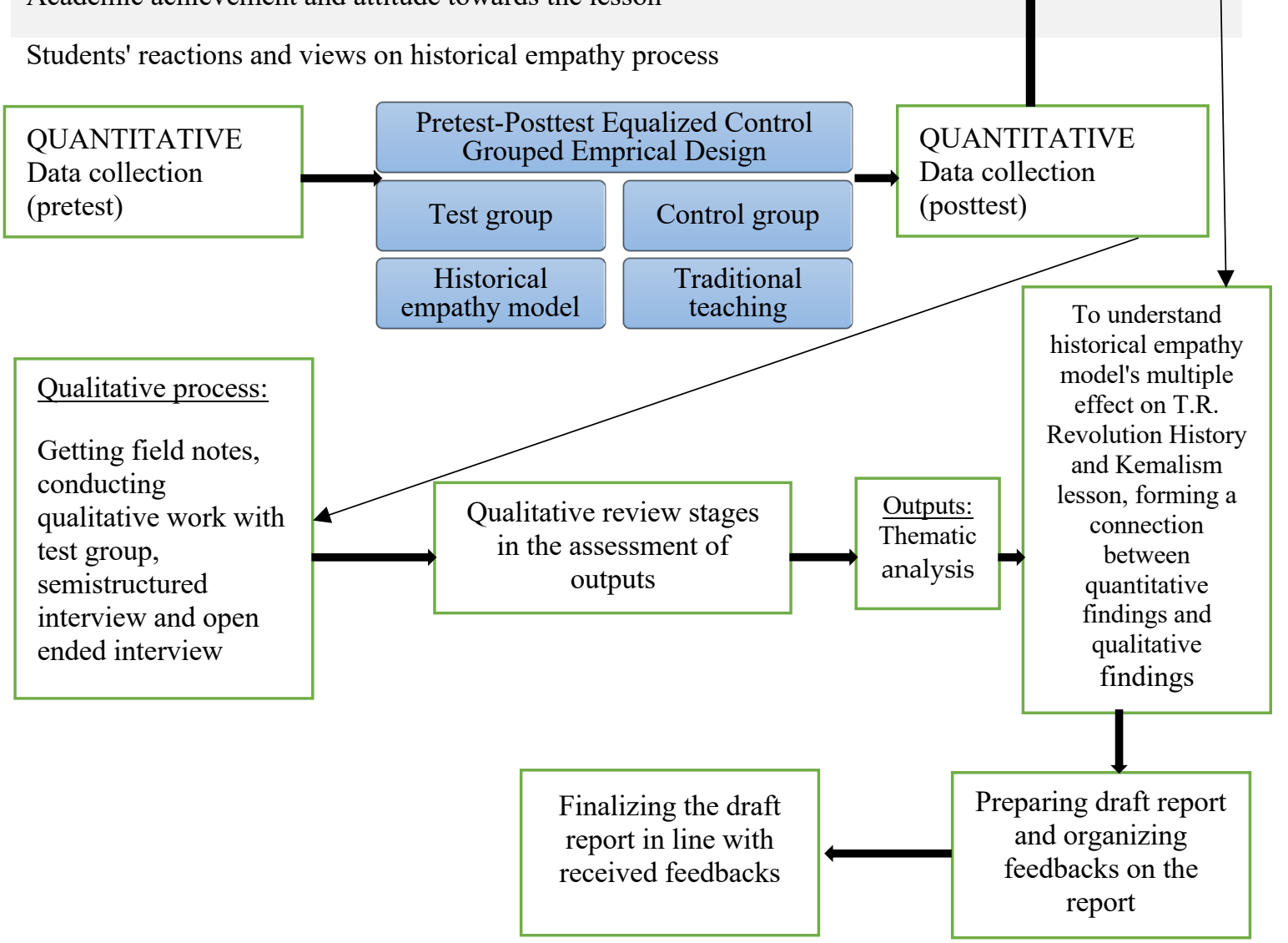

\section{Outputs:}

Item and factor analyses
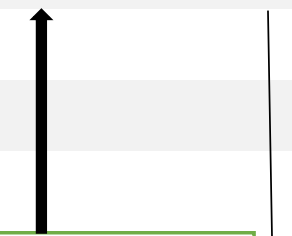

Figure 1. Explanatory mixed method design used in the research 
Research's study group included $8^{\text {th }}$ graders from two different sections during 2019-2020 academic year (7 October 2019 / 12 January 2020) in a public middle school from Ferizli district of Sakarya city. Within the scope of the study, research permission no. 29065503E.18609769 was obtained. The research was carried out in a rural area of Sakarya, which is a large-scale city according to population criteria close to the Black Sea coast. In this region, there is a primary school and a health center, electricity and drinking water networks, fixed telephone and ADSL connection; however, there are no infrastructure services such as post office and sewerage network. In addition, transportation is provided by asphalt road. The majority of Bulgarian immigrants and people coming from the Black Sea region live in the region.

Total number of participants is 54 but since two students from test and control groups each failed to attend lessons due to different reasons, they were excluded from the research. Participants within experimental procedure were designated according to multi-level mixed method sampling approach. In multi-level mixed method sampling approach, more than one stage can be followed to identify study group or sampling and in each stage qualitative or quantitative data can be utilized (Teddlie and $\mathrm{Yu}, 2007$ ). In this research too, a list of stages were followed to detect test and control groups and in every stage qualitative or quantitative data were harnessed. After receiving required approvals from Anadolu University Social and Human Sciences Research and Publication Ethics Board and Sakarya Provincial Directorate of National Education, the middle school to conduct the experimental procedure was designated. To that end at first middle schools with minimum two sections and a minimum of 20 students in every section were determined. Besides, classes in which number of girl and boy students are balanced and students who could manage to submit the activities and tasks regularly and timely were selected. When all these criteria were taken into account, a middle school with a school library that contained several primary and secondary sources and testimonies was selected as the research site since this school also had two sections and 25 students in each section. Upon detecting school and classes for the research practice, next step was determining test and control groups. Test and control groups could not be randomly assigned since school management already assigned the classes. Therefore, the research was administered among given groups; yet in experimental researches if random assignment is infeasible what matters is equalizing test and control groups with respect to some critical variables. Some of the demographic features belonging to study group are as shown in Table 1. 
Table 1

Demographic Features of Students in Test and Control Groups

\begin{tabular}{|c|c|c|c|c|c|}
\hline \multicolumn{2}{|l|}{ Demographic features } & \multicolumn{2}{|c|}{ Test group } & \multicolumn{2}{|c|}{ Control group } \\
\hline \multirow{4}{*}{ Gender } & & $\mathrm{f}$ & $\%$ & $\mathrm{f}$ & $\%$ \\
\hline & Girl & 14 & 56 & 15 & 60 \\
\hline & Boy & 11 & 44 & 10 & 40 \\
\hline & Total & 25 & 100 & 25 & 100 \\
\hline \multirow{4}{*}{ Age } & 13 & 5 & 20 & 8 & 32 \\
\hline & 14 & 20 & 80 & 16 & 64 \\
\hline & 15 & - & - & 1 & 4 \\
\hline & Total & 25 & 100 & 25 & 100 \\
\hline \multirow{8}{*}{$\begin{array}{l}\text { Monthly income level } \\
\text { of the family }\end{array}$} & Below $2020 \mathrm{TL}$ & 1 & 4 & 6 & 24 \\
\hline & $2020 \mathrm{TL}$ & 3 & 12 & 4 & 16 \\
\hline & Between 2020-2500 TL & 6 & 24 & 4 & 16 \\
\hline & Between 2501-3000 TL & 12 & 48 & 3 & 12 \\
\hline & Between 3001-3500 TL & - & - & 2 & 8 \\
\hline & Between 3501-4000 TL & 1 & 4 & 2 & 8 \\
\hline & $4001 \mathrm{TL}$ and above & 2 & 8 & 4 & 16 \\
\hline & Total & 25 & 100 & 25 & 100 \\
\hline
\end{tabular}

\section{Quantitative Stage}

Since the aim was to analyze independent variable's (historical empathy model) effect on dependent variable (Academic achievement and attitude towards Middle School T.R. Revolution History and Kemalism lesson) there was need for quantitative method. To that end, an experimental setup was formed. To collect quantitative data, academic achievement test and attitude scale towards Middle School T.R. Revolution History and Kemalism lesson was developed. Thus, collected data could be statistically analyzed so as to perform a comparison between groups. Research's quantitative stage was performed in accordance with pretestposttest equalized control grouped experimental design.

\section{Quantitative Data Collection Tools}

To answer questions in the quantitative stage of research; attitude scale developed towards academic achievement test and Middle School T.R. Revolution History and Kemalism lesson was utilized. 


\section{Academic achievement test}

In the research achievement test developed by Elbay (2020a) for Unit 2: "National Awakening: Steps taken towards Independence” in Middle School T.R. Revolution History and Kemalism lesson was used. KR20 reliability coefficient of the test was measured as 0,771; mean index of distinctiveness was 0,461 and difficulty index was 0,542 . Within the scope of reliability and validity, achievement test developed according to these results is taken to be in acceptable level.

\section{Attitude scale}

In the research, attitude scale developed by Elbay and Kaya (2020) towards Middle School T.R. Revolution History and Kemalism lesson was harnessed. To identify factor structure of the scale, exploratory and confirmatory factor analyses were made; next reliability and item analysis were conducted and in the end it was detected that the scale had a factor structure consisting of 22 items and 4 dimensions. For instance, Cronbach's Alpha value for all items was measured as ,939; first factor in its subdimensions as, 927 ; second factor as ,839; third factor as ,786 and fourth factor as ,655.

\section{Experimental procedure}

Experimental procedure was conducted in Middle School T.R. Revolution History and Kemalism lesson Unit 2; "National Awakening: Steps taken towards Independence". Experimental procedure was administered in line with historical empathy model. Lessons were instructed in line with specified stages and in every stage students were guided to engage in varied learning activities that match stages of historical empathy model. Stages in historical empathy model used in experimental procedure and activities conducted in these stages are as below:

i. Introduction stage: In general, the lesson started by asking open-ended questions (have you ever had to make a tough decision? If yes what made this decision tough?). By these questions it was aimed to help students realize that a historical event could have taken place under difficult circumstances and students were directed to associate their previous experiences with the historical event to explore. Lastly, significance of a 
historical event was emphasized and it was aimed to fuel motivation (Why do we have to find out the underlying causes behind the WWI?).

ii. Investigation stage: In line with related acquisition, lessons in this stage were taught in first and second hand sources. Various documents about the acquisitions (for example, 'First World War in Ottoman Documents 2' retrieved from Ottoman achieve) were analyzed by students under the observation of teacher/researcher. Next, various documentaries were played (such as, 'First World War from the Eyes of Arabs'). Hence students could be able to develop hypotheses on a historical event and comprehend this event within the scope of a historical context. Later, students' questions were directed to other students to fuel an in-class discussion. To help students understand the role of historical personalities, various memoirs (such as, Independence War memoirs of Kazım Karabekir Pasha) were reviewed. In this stage since language style of the memoirs was difficult to understand, teacher/researcher distributed to the students simplified versions of these narratives.

iii. Display stage: In this stage, students were asked to display their learnings and it was attempted to make the final product to reflect learning performances of students. Later, the product was assessed via grading scales. To that end, students performed an application according to historical context towards historical events at the focus of acquisitions, multiple perspectives and emotional factors (such as writing a historical narrative on what has been learnt). Thus it was possible to see what kind of a relationship students formed between evidences and sources, how they evaluated historical events and how they reflected them onto their historical comments.

iv. Reflection stage: In this stage, the aim was to find out if students changed their thoughts and emotions in Introduction stage. In that sense, a historical event (for instance causes behind First World War and developments leading to the war) was discussed; then researcher/teacher asked questions that connected the past with present day (such as, do you think there are still some societies or regions undergoing the same conditions, is that some kind of a conflict of interest?).

\section{Quantitative Data Analysis}

In order to answer clause (a) of research's first question One-Way Covariance Analysis (Ancova) was used. This analysis was chosen since, by eliminating uncontrollable destructive 
factors via linear regression analysis, it could unveil the factual effect of experimental procedure. Besides, for the effect size of experimental procedure, partial eta square ( $\eta 2)$ value was computed and its effect was reported. In order to answer clause (b) of research's first question Multi-variant Anova (Manova) was harnessed. In sum, when experimental procedure ended Manova was administered to detect if a significant difference existed between posttest attitude scores of test and control groups. This analysis was chosen to test if a significant difference existed with respect to sub-factors of attitude scale of test and control groups.

\section{Qualitative Stage}

In the second stage of research it was aimed to explain effects of historical empathy process on academic achievement and attitude. To that end it was aimed to unveil the way historical empathy process molded students' reactions and views. That is an evidence of the fact that second stage of the research was performed according to heuristic design. This design that lacks a directive structure could be suitable to examine a phenomenon (historical empathy process) since it started as qualitative.

\section{Qualitative Data Collection Tools}

To answer research's second question lessons conducted in test group were video recorded and a semi-structured interview form was designed.

\section{Video camera}

While teaching the "National Awakening: Steps Taken Towards Independence" unit, the lectures were recorded on video camera. In this research one 64 GB flash disk, and a video camera with $4 \mathrm{~K}$ feature and 1080p resolution were utilized. Videos were shot in two main halls; classroom and library. So as to record student reactions in the widest perspective as possible, camera was mounted and fixed on top of the smart board. Video records saved in flash disk were regularly transferred to computer database every night after the shooting (at 7:00 p.m in general). Video recording took place between 24 Oct-12 Dec. 2019 during 7 class hours at approximately 245 minutes. Before the lessons were recorded on video camera, "the Parent 
and Student Consent Forms for Video Recording and Photographing" were read by the students and parents and these forms were signed by them.

\section{Semi-structured interview form}

Interview questions were concocted on the basis of semi-structured interviews observed in historical empathy literature and studies on historical empathy. These questions were then reviewed by 2 specialists in the fields of social sciences and history education and 1 social sciences teacher, in accordance with views and suggestions of experts, required corrections and changes were made on the questions. In the interview form 8 open-ended questions and 2 final questions with no directives were listed. Designed questions were administered as pilot study among $58^{\text {th }}$ graders. So as to clarify incomprehensible points during interview process to students, the form also included alternative items. After these interviews questions were revalued and a semi-structured interview form that integrated a total of 7 open-ended questions was designed. Semi-structured interview questions are as follows:

1. What do you understand when you say historical empathy?

2. What does historical figure remind you?

3. Do you think you have historical empathy? If yes, with which person (s) did you do that?

4. Did lessons taught with historical empathy help you understand historical events? If yes, how?

5. How were the lessons taught with historical empathy in your opinion?

6. Were the lessons taught with historical empathy different from those taught by other methods? If so, what were they?

7. What would you recommend to others in interpreting a historical figure or event?

\section{Qualitative Data Analysis}

Data collected to answer research's second question was analyzed via thematic analysis. Thematic analysis can call for a circular process in which data are gathered to direct data collection as well as analysis and in which analysis takes place concurrently (Merriam, 2009). In this regard thematic analysis was used to explain existing qualitative data since there was not a pre-designated theme or dimensions. Thus the aim was to reveal novel concepts and 
themes that were absent in pre-designated headings. While student views were examined, exceptional points in the views were noted and specific words and phrases were highlighted in red. In addition personal citations (in vivo) were saved in Excel program and this pre-analysis was an early preparation to code the views line by line. Line decodings done in the pre-analysis of interviews were compared with data retrieved from video camera; codes were then classified under specific categories. 127 codes and 28 categories attained in the first decoding tour were tabulated. That was in line with Merriam's (2009) view that; themes attained when first analyses are complete have preliminary features and it is yet impossible to exactly know under which categories these codes could be classified. That reality enabled to internalize multiple data set and in order to reveal differences and similarities in codes, it allowed to neutrally review the categories (Bogdan and Biklen, 2007). In the second analysis stage, to the end of showing bigger formations within data set, similar codes were united and 33 key codes were thus designed. Next, they were reduced to categories. In that case 28 categories emerging at the start were reduced to 13 in line with class division of codes. Therefore, during decoding process, redundant data were extracted. In the third stage categories were degraded into 3 main themes and for these themes pieces of evidence were searched within data set (word and word groups).

\section{Validity and Reliability (Trustworthiness)}

Trustworthiness stands for the value and credibility of findings (Lincoln and Guba, 1985). One way to secure credibility is conducting long-term observation and maintaining constant interaction with participants until the researcher fully grasps the investigated phenomenon (Glesne, 2015). That is to say in the research site, long-term observation (around 6 months) was conducted on the examined social phenomenon (reactions and views molded throughout historical empathy process) constant interaction with participants was maintained throughout the process. Peer review (Glesne, 2015) is one of the ways to attain credibility. Peer review mandates constant communication with colleagues and/or experts as the research continues and taking their opinions and evaluations into account. In this regard during the research there was continuous exchange of information on the procedural steps with 2 field experts and school principal in the middle school where the research was conducted; their opinions, suggestions and evaluations were reflected in the research process. In addition data diversification was 
achieved since more than one data collection tool was utilized in the research. Lastly, reliability between coders was computed. In that sense reliability formula (Reliability = Consensus/(Consensus+Dissensus)) suggested by Miles and Huberman (1994) was used. To that end a total of 3 people -one researcher and two social sciences field experts- independently coded interviews and video-record scripts. At the end of decoding, first coder 127, second coder 140, third coder 130 key codes were attained. First and second codes had consensus on 127 codes, dissensus on 13 codes (compatibility 91\%), first and third coders had consensus on 127 codes, dissensus on 3 codes (compatibility 98\%), second and third coders had consensus on 130 codes, dissensus on 10 codes (compatibility 94\%). Disputed codes were not included into the analyses.

\section{Findings}

\section{Quantitative Findings}

\section{Academic achievement}

To detect if a significant difference existed between pretest and posttest mean scores with respect to test and control groups' academic achievement, One-Way Ancova (Covariance) Analysis was utilized and in Table 2 outputs of this analysis have been listed.

Table 2

Ancova Analysis of Posttest Scores Corrected According to Academic Achievement Pretest Scores

\begin{tabular}{|c|c|c|c|c|c|c|c|}
\hline Variance source & Sum of squares & sd. & Mean of squares & $\mathbf{F}$ & $\mathbf{p}$ & $\begin{array}{c}\text { Partial } \\
\eta 2\end{array}$ & $\begin{array}{l}\text { Effec } \\
\text { t size }\end{array}$ \\
\hline Corrected model & $2800,520^{\mathrm{a}}$ & 2 & 1400,260 & 11,996 &, 000 & ,338 & ,993 \\
\hline Pretest & 952,200 & 1 & 952,200 & 8,157 & ,006 & , 148 & ,799 \\
\hline Group & 1274,630 & 1 & 1274,630 & 10,920 & ,002 & 189 & ,899 \\
\hline Error & 5486,200 & 47 & 116,728 & & & & \\
\hline Total & 105792,000 & 50 & & & & & \\
\hline Corrected sum & 8286,720 & 49 & & & & & \\
\hline
\end{tabular}

Table 2 displays that with respect to academic achievement pretest scores of test and control groups there is 05 level of significant difference between corrected posttest scores (F1$47=10,920 ; \mathrm{p}<.05)$. In another saying it became apparent that historical empathy model academic achievement in a statistically significant degree. 


\section{Attitude}

To detect if with respect to subdimensions (factors) of test and control groups' attitude scale towards Middle school T.R. Revolution History and Kemalism lesson significant difference persisted between pretest and posttest mean scores, one-factor Manova was applied. Results of Manova Analysis are as shown in Table 3 and 4.

Table 3

Manova Results of Test and Control Groups' Attitude Scale Factor Scores

\begin{tabular}{lllcccc}
\hline Effect & & Value & F & Hypothesis sd & Error sd & p. \\
\hline Education- & Pillai's Trace &, 980 & 41,584 & 8,000 & 40,000 &, 000 \\
axle & Wilks' Lambda &, 020 & 41,584 & 8,000 & 40,000 &, 000 \\
division & Hotelling's Trace & 8,317 & 41,584 & 8,000 & 40,000 &, 000 \\
& Roy's Largest Root & 8,317 & 41,584 & 8,000 & 40,000 &, 000 \\
Group & Pillai's Trace &, 242 &, 594 & 8,000 & 40,000 &, 158 \\
& Wilks' Lambda &, 758 &, 594 & 8,000 & 40,000 &, 158 \\
& Hotelling's Trace &, 319 &, 594 & 8,000 & 40,000 &, 158 \\
& Roy's Largest Root &, 319 &, 594 & 8,000 & 40,000 &, 158 \\
\hline
\end{tabular}

Table 3 evidences that there is not a significant difference between mean scores attained by test and control groups' attitude scale towards T.R. Revolution History and Kemalism lesson (Wilks' Lambda $=0,758, F(8,40)=0,594, \mathrm{p}>0,05)$. This finding reveals that with respect to mean scores received from entire scale there was not ,05 level of significant difference. Mean and standard deviation values related to scale's 4 factor and one-factor Anova results on the basis of factor are as illustrated in Table 4. 
Table 4

Mean and Standard Deviation Values and One-Factor Anova Results Test and Control Groups' Attitude Scale Factor Scores

\begin{tabular}{lllccccc}
\hline Subdimensions & Group & $\mathbf{N}$ & $\mathbf{X}$ & ss. & sd. & $\mathbf{F}$ & $\mathbf{p}$ \\
\hline \multirow{2}{*}{ Rest } & Test & 24 & 72,6917 & 19,59680 & $1-47$ & 2,621 &, 112 \\
\multirow{3}{*}{ Value } & Control & 25 & 64,0640 & 17,69508 & & & \\
\multirow{3}{*}{ Motivation } & Test & 24 & 77,2933 & 17,16781 & $1-47$ & 2,099 &, 154 \\
& Control & 25 & 69,8016 & 18,94008 & & & \\
Benefit & Test & 24 & 77,6875 & 23,29574 & $1-47$ & 6,997 &, 011 \\
& Control & 25 & 58,9600 & 26,11390 & & & \\
& Test & 24 & 70,1250 & 20,20829 & $1-47$ & \multirow{2}{*}{, 152} &, 698 \\
& Control & 25 & 67,7600 & 22,15529 & & & \\
\hline
\end{tabular}

Table 4 reveals that between motivation mean scores of test and control groups there was ,05 level of significant difference $(F(1-47)=6,997, p<0,05)$, however in terms of other dimensions there was no significant difference $(p>0,05)$.

\section{Qualitative Findings}

Students' views towards historical empathy process are displayed in Table 5.

Table 5

Students' Views Towards Historical Empathy Process

\begin{tabular}{lllr}
\hline Theme & Category & Code & n \\
& & & 6 \\
\hline $\begin{array}{l}\text { Demonstrating } \\
\text { multiple literacies }\end{array}$ & Presenting historical thinking skills & Making historical questioning & 5 \\
& & Making historical criticism & 12 \\
& Using information and & Multidimensional effect by the Videos & 8 \\
& communication technologies & Multidimensional effect by worksheets & 4 \\
& Demonstrating interpersonal and & Multidimensional effect by visual tools & 12 \\
& group skills & Engaging in group discussions & 6 \\
\hline Taking historical & Having awareness on historical & Interpreting historical conditions based on & 13 \\
context into & period & period & 9 \\
account & & Arguing that periods differ from each other & 9 \\
& Having multiple points of view & Dual perspective towards historical events & 5 \\
& & Neutral perspective towards history & 13 \\
\hline Emotional & Forming attitude & Forming positive attitude towards the course & 13 \\
reaction & & Forming negative attitude towards the course & 3 \\
& Making negative associations & Difficulty and toughness of lessons taught in & 1
\end{tabular}




\section{Theme 1: Developing multiple literacies}

Demonstrating historical thinking skills: It was observed that many of the students demonstrated multidimensional historical thinking skills. In this regard, it was stated that students demonstrated historical questioning (Emrullah, Eser, Rukiye, Müslüme, Sidıka, Özcan) and criticism (Emrullah, Eser, Okan, Selime, Ali).

Some of the students argued that thanks to historical empathy, they could perform historical questioning. For instance Eser-coded student stated specific topics to illustrate how he could engage in historical questioning:

"Historical empathy allows me to question in class. It helped me indeed. Like Kuvâyı Milliye (Nationalist Forces). Why did Kuvâyı Milliye fight? Because there was no army in that time and these forces did not want to lose as a nation. They were not pessimistic, it was a fight. Coursebook on its own could not teach me that much. I think about those ages and reflect on my own."

Rukiye-coded student stated that lessons taught in historical empathy helped her historical questioning but other methods had no such benefit and that in other lessons mostly teachers performed questioning:

"We engage in questioning with historical empathy. Why did this man do all of them, what was his motive? In other methods it is only the teacher questioning because s/he talks from own point of view. We cannot express our own viewpoint. Teacher talks from own perspective, which is perhaps not true for me. When I add my thoughts and comments, it is more effective indeed."

Using information and communication technologies: It was identified that a vast majority of students benefited multidimensionally from information and communication technologies. In this regard we can argue that students were affected by video (Emrullah, Hasan, Hamiyet, Kadir, Rukiye, Behzat, Ecrin, Mehtap, Müslüme, Soner, Özcan, Ali), visual tool (Emrullah, Kadir, Rukiye, Mehtap) and worksheets (Kadir, Şengül, Ecrin, Mehtap, Müslüme, Sıdıka, Özcan, Ali) in a multidimensional aspect.

Many students attested that videos from old periods were particularly useful in storing in their minds. In the same vein Emrullah-coded student said, "Videos etc. helped me a lot to 
remember. Videos and other things stay in my mind longer. " Rukiye- coded student said videos grabbed their attention and that was probably related to background music in the videos.

"For me one thing was noticeable in video; background music. That music turns the video into a majestic piece and you immediately focus on the story. Even if you have no desire to watch, it draws you in and you cannot stop looking at it. In line with the excitement there, the background music is passionate, depending on the gloom background music becomes emotional and squeaky. It just takes my attention. I feel like I am inside the story and I try to picture myself in there. If I were there could they have done them to me? How would I react? I position myself right into the video as one of the actors."

Rukiye-coded student employed 'a tree with many branches' metaphor and stated that visual tools helped more than texts. Here are her views:

"They were all schematized. They all were like many branches rising above a tree. Like a tree and you make a generic tree from the branches of this tree and that tree draws your attention. Branches transform it into an adorable tree. It is beautiful just because of that but when some texts are too long, they become boring. If there are only words it is unbearable but if it is divided into branches, schematized, there are lines, and a map is put then it is much better. Maps are great visual aids. But if there is even a text, there should be a diagram and text boxes; they are really much better but if it is only text if there is no visual it is just boring."

Demonstrating interpersonal and group skills: A great number of students stated that they demonstrated interpersonal and group skills. In this regard students said they engaged in group discussions (Hamiyet, Kadir, Şengül, Ecrin, Rukiye, Mehtap, Müslüme, Zülal, Soner, Sıdıka, Özcan, and Ali) and formed constructive group interactions (Emrullah, Hamiyet, Rukiye, Behzat, Mehtap, and Okan).

Students generally stated that discussions provided dialectic effect. In this regard Müslümecoded student remarked that:

"Discussions are great, I believe. Maybe I think incorrectly about a topic or my friends think wrongly. This is how I coded that topic on my mind. The more I discuss with my classmates I can draw more logical conclusions and construct better sentences. Topics then become much clearer." 
On the other hand Zülal-coded student stated that even without taking part in discussions, topics could still be well understood, "In my opinion discussions were great because they reached a decision at the end of discussions; and thanks to these discussions I could understand the topics." Furthermore, some students stated to have formed a constructive group interaction. For example Hamiyet-coded student shared her views such; "teamwork was great. At least you have a chance to hear everyone's opinion." thus emphasizing the democratic aspect of group works. Rukiye-coded student agreed that group works were useful in taking different points of views and solving the disagreements in a constructive way:

"Teamwork was good. We write on our own. We jot down our personal views and view the events from our perspective. Even more, that allows us to find out others' thoughts and their perspectives towards the events. If there are incorrect ways in their approach, we can correct them too. If I am wrong in terms of some aspects, they can also correct my wrong ways."

\section{Theme 2: Taking historical context into account}

Having awareness on historical period: It became apparent that most of the students thought as per historical circumstances in that period. Hence it can be claimed that students tried to interpret historical personalities and events according to existing historical period (Raziye, Hasan, Hamiyet, Şengül, Rukiye, Okan, Zülal, Soner, Ali, Esma, Özcan, Sakine, Eser, Ecrin) and argued that historical periods had their own differences (Esma, Emrullah, Raziye, Eser, Hamiyet, Rukiye, Zülal, Salih, Özcan) .

It was identified that most of the students attempted to interpret historical events and personalities with respect to its historical period. For instance Şengül-coded student stated that,

"Vahdettin is not a traitor because he was already the Sultan so why would he ever want to destroy his own nation? In fact he signed Mondros Treaty to put an end to the war. He wanted to save himself too. He did not sell his country; however his aspiration was not independence whatsoever. He wanted to live under the mandate and guardianship of Entente Powers."

Her statement is a clear example of interpreting a historical event (Mondros Treaty) from the viewpoint of a historical character (Sultan Vahidettin) ("He wanted to save himself too. He did not sell his country; however his aspiration was not independence whatsoever. He wanted to 
live under the mandate and guardianship of Entente Powers"). In addition to all it was detected that some of the students argued that historical periods differed from each other. In this regard Esma-coded student shared her views as such:

"It is most important to be aware of the existing conditions then; what was happening during that time? Since we learnt about those times we already know them in our age. Those were the last ages of Ottoman State; we should be able to think like people living in those times. Our age and their age are totally different."

Having multiple points of view: Students were observed to analyze historical events from two aspects (Raziye, Kadir, Rukiye, Behzat, Ecrin, Zülal, Soner, Özcan, Ali) and tried to judge history neutrally (Raziye, Hasan, Şengül, Rukiye, Müslüme). Some of them stated the need to analyze historical events from two aspects. In addition some students remarked the need to judge history from a neutral perspective. That being said Raziye-coded student stated the need to judge history in light of evidences from a neutral perspective:

"If only we could travel in time so that we could see the facts first handedly. We could understand truly and one hundred percent. If we take a look at the Turkish and American newspapers in that age in America Americans defend their nation and in here Turks defend themselves while blaming Americans. This is why our minds are blurred a little. Let's say Americans have some issues with Turks. Not to put themselves into criminal position they of course blame Turks but then how would Turks react? That would damage their pride, even if there is something faulty, Turks would criticize America not themselves... It is not just U.S-Turkey problem. There are other states too. We have to learn from the things we read because we do that to unveil the evidences and interpret on our own; but we should stay away from mixing our own emotions and thoughts: We can't say 'This is what made me sorry most" but instead comment like that; 'This is a clear sign that the nation was in trouble as seen in that time'.

\section{Theme 3: Emotional reaction}

Forming attitude: It was seen that most of the students shared various attitude and value expressions towards T.R. Revolution History and Kemalism lesson. In this regard it was detected that students had positive (Emrullah, Eser, Hasan, Sakine, Rukiye, Mehtap, Müslüme, Soner, Sıdıka, Şengül, Özcan, Zehra, Esma, Zülal) and also negative attitudes (Cemile, Mehtap, Hamiyet) towards T.R. Revolution History and Kemalism lesson. 
A vast majority of students claimed that thanks to historical empathy they developed positive attitudes towards T.R. Revolution History and Kemalism lesson. Sidika-coded student however stated that at the start she was not keen on history but thanks to historical empathy, she started to enjoy the course:

"The truth is if we just read from course book it wouldn't be possible for us to visualize many of the events told. But with historical empathy I can visualize them and I think it is fun. Just reading an ordinary text is not that much interesting for our classmates. That is true for all the other lessons too. Take Kadir, for example, normally he has no interest for history but he likes this lesson. Normally I don't like either. When the lesson is based on course book it doesn't attract me but once we have such varied contexts I do love it. I am more attached to it. I used to dislike History and I never watched history movies but as we watch these videos in class, I am much more fond of it now. I didn't like it before, I thought it was very boring but once I managed to understand the events, it intrigued me even more."

Making negative associations: Some students complained that lessons in historical empathy were difficult and tiring in essence (Raziye) and that forming historical empathy was a futile attempt (Ali). Raziye-coded student claimed that, "I think studying lesson in that way is really hard and tiring." illustrating the challenging and difficult nature of lessons in historical empathy while Ali-coded student stated that "I think it was futile" as a way to demonstrate his belief in the futility of historical empathy.

\section{Combining Quantitative and Qualitative Findings: Employing Qualitative Data to Understand the Results of Experimental Procedure Implemented to Test the Effect on Academic Achievement and Attitudes towards the Lesson}

Final results obtained via blending quantitative and qualitative findings are as demonstrated in Table 7. 
Table 7

Blending the Findings Obtained from Quantitative Data Collection Tools and Findings from

Qualitative Data Collection Tools

Quantitative finding Qualitative finding $\quad$ Quant $\rightarrow$ qualit. $=$ results

\section{Effect on Academic Achievement}

Compared to students in control group where the lessons were taught in traditional teaching, there was a statistically significant increase in the academic achievement levels of students in test group where the lessons were taught in historical empathy model (F1$47=10,920 ; \mathrm{p}<, 01)$.
During historical empathy process it was observed that students;

- $\quad$ Reviewed various and different types of first and second hand documents (resource and evidence),

- They could initiate discussions,

- They could continue discussions and

- They could ask questions.

It was detected that the reflections of historical empathy process on students' views are;

- Multiple literacies and

- Taking historical context into account.

\section{Limitations with the Acquisitions:}

Difficulty of some students $(n=5)$ in understanding historical events

\section{Effect on the attitudes towards the lesson}

Compared to students in control group where the lessons were narrated in traditional teaching, there was not a significant difference in the mean scores from attitude scale obtained by students in test group where historical empathy model was followed in lessons (Wilks' Lambda $=0,758, F(8,40)=0,594, p>0,05)$. However;

- In relation to motivation subfactor mean scores of the scale, there was ,05 1 significant difference between test and control groups( $\mathrm{F}(1-$ $47)=6,997, p<0,05)$.

In addition compared to students in control group students in test group obtained higher posttest mean attitude scores from subdimensions such as; Rest, Value and Benefit.
In historical empathy process students' reactions were observed such;

- Excitement,

- Rage, and

- Boredom.

Historical empathy was reflected on students' views in such way; emotional reactions (forming positive and negative attitudes towards the lesson).
Potential reasons that explain how historical empathy model would elevate academic achievement:

In historical-empathy modeled lessons, it might be easier to understand the topics and participate in class discussions. In this regard it can be argued that listening-focused activities (discussion, video, photos, various documents etc.) would facilitate following the unit contents.

It was monitored that in historical empathy process students took part in the lesson enthusiastically, viewed a historical event and personalities in rage, motivated for the lesson, felt joyful in lesson, developed a feeling of love and respect for historical personalities hence all in all they have adopted positive attitudes towards T.R. Revolution History and Kemalism lesson. Despite that some students were bored in class hours $(\mathrm{n}=3)$ and considered forming historical empathy as a futile attempt $(n=1)$ thus they have adopted negative attitudes towards the lesson. 


\section{Discussion and Conclusion}

At the end of the research it was observed that historical empathy model followed in T.R. Revolution History and Kemalism lesson elevated academic achievement of students in a significant level. In the same vein studies conducted by Çorapçı (2019) and Demir (2019) among $7^{\text {th }}$ graders demonstrated that thanks to activities performed within the context of historical empathy among middle school students, there was significant rise in their academic achievement. In parallel with these studies a research by Hartmann and Hasselhorn (2008) proved that students who exhibited high level of contextualization, as one aspect of historical empathy, managed to get high grades in history lesson.

In the research it also became apparent that historical empathy model followed in T.R. Revolution History and Kemalism lesson failed to increase students' attitudes towards the lesson in a significant level; however it was also detected that posttest attitude mean scores of students in test group that followed historical empathy model were, compared to control group in which traditional teaching was applied, significantly higher. Likewise a study by Çorapçı (2019) proved that historical empathy had not any significant effect on $7^{\text {th }}$ graders' attitude towards social studies lesson; on the other hand it was also manifested that compared to control group students, students in test group where activities were based on historical empathy, mean scores obtained from posttest in social sciences lesson were higher. In accordance Savaş and Aslan (2014) in their study detected that by means of history based films played in middle school T.R. Revolution History and Kemalism, students were able to develop historical empathy and as a consequence they developed positive views towards the lesson.

In the research it was revealed that students agreed that historical empathy offered various contributions to develop multiple literacies. It can be argued that via historical questioning and criticism, students shared their views that aligned with their historical thinking skills. In that sense Gürsoylar (2019) and Doğan (2019) in their research reported that history teaching based on historical empathy improved historical thinking skills of $8^{\text {th }}$ graders. Echoing these results a vast number of studies proved that historical empathy offered immense benefits for historical criticism and questioning which were sub-skills of historical thinking (Endacott and Brooks, 2013; Levstik and Barton, 2001). 
It was revealed in the research that the views of students have reflected their attention to historical context. Within that scope students expressed various views related to historical period perception and multiple points of view. It can this be argued that students viewed historical conditions and personalities, cognitive factors at most, with a higher level of awareness and tried to analyze historical events multidimensionally. Further to that, it is viable to form a connection between quantitative test results of student and adopting multiple perspectives. According to quantitative test results compared to control group students that were educated in traditional teaching model, students in test group that followed historical empathy model were more successful in acquisition-focused (comprehension, analysis and evaluation based test) achievement test and this can be seen as a sign that students were able to make historical comments and therefore adopting multiple perspectives. That is because as argued by Demircioğlu (2010) students who reach to historical analysis and interpretation level can demonstrate multiple perspectives. On the other hand students' ability to detail conditions in the past can allow them to take into account concrete samples in forming new data (Beishuizen, Asscher, Prinsen and Elshout-Mohr, 2003). In that sense it was detected that students provided concrete samples from the past (making bread from peanut shells etc.)

It was detected that students expressed emotional statements towards the lesson. In this regard students at first reported that via historical empathy they were more interested and motivated for the course. In the same vein relevant studies showed that thanks to the activities related to historical empathy students adopted positive attitudes (Çorapçı, 2019; Savaş and Aslan, 2014), developed greater interest towards the lesson (Gürsoylar, 2019), felt motivated, joyful in class (Doğan, 2019) and the lesson turned out to be fun and enjoyable (Kaygisız, 2019). Besides it was detected in the research that some students considered the lesson to be dull and felt bored in the lesson. As a consequence it is expected that this is why some of the students considered engaging in historical empathy to be a futile attempt.

\section{Suggestions}

- In order to elevate academic achievement in T.R. Revolution History and Kemalism lesson it is suggested to employ by social studies teachers historical empathy model.

- Since the T.R. History of Revolution and Kemalism lesson is taught in the last year of middle school ( $8^{\text {th }}$ grade $)$ in Turkey, there are 10 questions from this course representing 
social sciences in the High School Entrance Exam. This situation shows that the lesson is in an effective position in guiding students for the future. Therefore, methods, techniques and tools used in the historical empathy model (such as historical narratives, group discussions, character sketches about historical personalities) can be used to increase academic achievement in both process-based cognitive learning and resultbased examinations.

- In the T.R. Revolution History and Kemalism lesson, it is suggested to employ by social studies teachers historical empathy model by considering motivators to help students' better learning (historical film, music, documentaries and discussions).

- Practitioners can benefit from historical empathy in the acquisition of many skills (such as decision-making, collaboration, critical thinking, using evidence and resources) and value (such as scientificity, love, respect).

- By means of historical empathy model, teaching could be performed on the basis of individual differences and it could hone skills such as adopting historical period approach and having multiple points of view. Thus practitioners could employ historical empathy model to integrate students more efficiently into teaching and learning process and also to adapt their lessons in a way to better match with history teaching concepts.

- In the teaching of historical subjects, studies designed according to a real and / or quasiexperimental pattern can be carried out for the effect of the historical empathy model on the permanence of students' academic achievement.

- It is also suggested to investigate the reasons of having difficulty in understanding historical events for some students and accordingly action-based studies could be implemented to correct this deficit.

\section{Statements of Ethics and Conflict of Interest}

"I, as the Corresponding Author, declare and undertake that in the study titled as "Understanding the Multiple Effects of Historical Empathy: A Study Explanatory Mixed Method", scientific, ethical and citation rules were followed; Turkish Online Journal of Qualitative Inquiry Journal Editorial Board has no responsibility for all ethical violations to be 
encountered, that all responsibility belongs to the author/s and that this study has not been sent to any other academic publication platform for evaluation."

\section{References}

Ashby, R., \& Lee, P. (1987). Children's concepts of empathy and understanding in history. In C. Portal (Ed.), The History curriculum for teachers (pp. 66-88). New York: Falmer.

Barton, K., \& Levstik, L. (2004). Teaching history for the common good. Mahwah, NJ: Lawrence Erlbaum Associates.

Bartelds, H., Savenije, G. M., \& Boxtel, C. V. (2020). Students' and teachers' beliefs about historical empathy in secondary history education. Theory \& Research in Social Education, 48(4), 529-551.

Beishuizen, J., Asscher, J., Prinsen, F., \& Elshout-Mohr, M. (2003). Presence and place of main ideas and examples in study texts. British Journal of Educational Psychology, 73, 291-316.

Brooks, S. (2008). Displaying historical empathy: What impact can a writing assignment have? Social Studies Research and Practice, 3(2), 130-146.

Bryant, D., \& Clark P. (2006). Historical empathy and Canada: A people's history. Canadian Journal of Education, 29(4), 1039-1064.

Creswell, J. W., \& Plano Clark, V. L. (2018). Karma yöntem araştırmaları tasarımı ve yürütülmesi (Y. Dede, \& S. B. Demir, trans.). Ankara: Anı Yayıncılık.

Çalışkan, H., \& Demir, B. (2019). Ergenlerde tarihsel empati ölçeğinin geliştirilmesi: Geçerlik ve güvenirlik çalışması. Turkish History Education Journal, 8(1), 129-149.

Çorapçı, S. (2019). Sosyal Bilgiler dersinde tarihsel empati etkinliklerinin ögrencilerin akademik başarı, kalıcılık ve derse karşı tutumlarına etkisi (Unpublished mastery dissertation). Recep Tayyip Erdoğan University, Rize.

De Leur, T., Boxtel, C. V., \& Wilschut, A. (2017). 'I saw angry people and broken statues': Historical empathy in secondary history education. British Journal of Educational Studies, 65(3), 331-352.

Demir, B. (2019). Sosyal Bilgiler dersinde tarihsel empatiye dayalı etkinliklerin ögrencilerin tarihsel empati becerilerine ve başarllarına etkisi (Unpublished mastery dissertation). Sakarya University, Sakarya. 
Demircioğlu, G. H. (2010). Tarih öğretiminde öğrenci merkezli yaklaşımlar. Ankara: Anı Yayınc1lik.

Dillenburg, M. (2017). Understanding historical empathy in the classroom (Unpublished doctoral dissertation). Boston University, Boston.

Doğan, B. (2019). Ortaokul T.C. Inkılap Tarihi ve Atatürkçülük dersinde "Atatürkçülük ve Çağdaşlaşan Türkiye" ünitesinin tarihsel empati ile öğretimi: Fenomenolojik bir çalışma (Unpublished mastery dissertation). Marmara University, İstanbul.

Elbay, S. (2020a). T.C. İnkılap Tarihi ve Atatürkçülük dersi 2. ünitesine yönelik kazanım odaklı başarı testi geliştirme çalışması. E-Uluslararası Eğitim Araştırmaları Dergisi, 11(1), 53-68.

Elbay, S. (2020b). T.C. İnkılap Tarihi ve Atatürkçülük öğretiminde duyuşsal ve bilişsel öğrenme etkinliklerinin tarihsel empatiye yansımalarının incelenmesi. Turkish History Education Journal, 9(1), 46-65.

Elbay, S., \& Kaya, E. (2020). T.C. İnkılap Tarihi ve Atatürkçülük dersine yönelik tutum ölçeği geliştirme çalışması. Zeitschrift Für Dir Welt Der Türksen / Journal of World of Türks, 12(1), 321-344.

Endacott, J. L., \& Brooks, S. (2013). An updated theoretical and practical model of historical empathy. Social Studies Research and Practice, 8(1), 41-58.

Foster, S. J. (2001). Historical empathy in theory and practice: Some final thoughts. In O. Davis, E. A. Yeager, \& S. J. Foster (Eds.), Historical empathy and perspective taking in the social studies (pp. 167-182). New York, NY: Rowman and Littlefield.

Glesne, C. (2015). Nitel araştırmaya girişs (A. Ersoy, \& P. Yalçınoğlu, trans.). Ankara: Anı Yayıncilik.

Güneş, S. (2019). Sosyal Bilgiler dersinde yaratıcı drama yöntemiyle tarihsel empati becerisinin kazandırılmasına yönelik etkinlik temelli bir eylem araştırması (Unpublished mastery dissertation). Bartın University, Bartın.

Gürsoylar, G. (2019). Ortaokul 7. sınıf Sosyal Bilgiler dersi kültür ve miras ögrenme alanının ögretiminde tarihsel empatinin kullanılması: Bir eylem araştırması (Unpublished mastery dissertation). Marmara University, İstanbul.

Hartmann, U., \& Hasselhorn, M. (2008). Historical perspective taking: A standardized measure for an aspect of students' historical thinking. Learning and Individual Differences, 18, 264-270. 
Jun, H. (2020). "I think the comfort women are us": National identity and affective historical empathy in students' understanding of “comfort women” in South Korea. The Journal of Social Studies Research, 44, 7-19.

Kaygısız, N. (2019). Tarihsel empati etkinlikleriyle işlenen Sosyal Bilgiler derslerinin öğrenci ürün ve görüşlerine göre incelenmesi (Unpublished mastery dissertation). Sakarya University, Sakarya.

Kosti, K., Kondoyianni A., \& Tsiaras A. (2015). Fostering historical empathy through dramaineducation: A pilot study on secondary school students in Greece. Drama Research, $6(1), 1-23$.

Levstik, L., \& Barton, K. C. (2001). Doing history: Investigating with children in the elementary and middle schools. Mahwah, NJ: Lawrence Erlbaum Associates.

Lincoln, Y. S., \& Guba, E. G. (1985). Naturalistic inquiry. Newbury Park, CA: Sage Publications.

Merriam, S. B. (2009). Qualitative research. A guide to design and implementation. San Francisco, CA: Jossey-Bass.

Metzger, S. A. (2012). The borders of historical empathy: Students encounter the holocaust through film. Journal of Social Studies Research, 36(4), 387-410.

Miles, M.B., \& Huberman, A. M. (1994). Qualitative data analysis. Thousand Oaks, CA: Sage.

Savaş, B., \& Aslan, Ö. (2014). T.C. İnkılap Tarihi ve Atatürkçülük dersinin öğretiminde filmlerin kullanımına ilişkin öğrenci görüşleri. 21. Yüzyılda Eğitim ve Toplum Eğitim Bilimleri ve Sosyal Araştırmalar Dergisi, 3(8), 129-148.

Savenije, G. M., \& De Bruijn, P. (2017). Historical empathy in a museum: Uniting contextualisation and emotional engagement. International Journal of Heritage Studies, 23(9), 832-845.

Shemilt, D. (1984). Beauty and the philosopher: Empathy in history and classroom. In A. Dickinson, P. Lee, \& P. Rogers (Eds.), Learning history (pp. 39-84). London: Heinemann Educational Books Ltd.

Teddlie, C., \& Yu, F. (2007). Mixed methods sampling: A typology with examples. Journal of Mixed Methods Research, 1(1), 77-100.

Yılmaz, K. (2011). Sosyal bilgiler ve tarih öğretiminde tarihsel empati: Geçmişe geçmişteki insanların gözüyle bakabilme becerisi. R. Turan, A. M. Sünbül, \& H. Akdağ (Eds.), Sosyal bilgiler ögretiminde yeni yaklaşımlar-II içinde (ss. 12- 33). Ankara: Pegem Akademi Yayıncılık. 